\title{
REWARD DAN PUNISHMENT DALAM PEMBENTUKAN KARAKTER DISIPLIN SANTRI
}

\section{REWARD AND PUNISHMENT IN THE FORMATION OF DISCIPLINE CHARACTERS SANTRI}

\author{
R Ulfah' ${ }^{1 a}$, RSP Fauziah ${ }^{1}$, dan RR Aliyyah ${ }^{2}$ \\ 1 Program Studi Manajemen Pendidikan Islam, Fakultas Keguruan dan Ilmu Pendidikan, \\ Universitas Djuanda Bogor, Jl. Tol Ciawi No. 1 Kotak Pos 35 Ciawi Bogor 16720 \\ 2 Program Studi Pendidikan Guru Sekolah Dasar, Fakultas Keguruan dan Ilmu Pendidikan, \\ Universitas Djuanda Bogor, Jl. Tol Ciawi No. 1 Kotak Pos 35 Ciawi Bogor 16720 \\ a Korespondensi: Resma Ulfah, Email: resmaulfah@gmail.com
}

(Diterima: 19-07-2018; Ditelaah: 20-07-2018; Disetujui: 18-09-2018)

\begin{abstract}
Education efforts in the formation of one discipline character is by using reward and punishment methods. It is rare for educational institutions that combine reward and punishment methods in one container. But Pondok Pesantren Moderm is an Islamic educational institution that is able to combine the two methods in one container and make it a culture in every modern pesantern hut. as applied in Pondok Pesantren Modern Daarul Uluum Bantarkemang. Pondok Pesantren this method of reward and punishment in disciplining santri. The purpose of this research is to understand reward and punishment in the formation of santri characters. This study used qualitative methods with ethnographic research used to examine the natural cultural values. Technique of collecting data is done by using; interviews, observation, and documentation. Data analysis using; Spradley model analysis, data collection, data reduction, display / data presentation and verification. The validity check of data uses source triangulation and uses reference material. The results of this study show: (1) Modern Boarding School Daarul Uluum Bantarkemang combining the concept of salafi and general learning, that is by studying the traditional books and madrasah schools; (2) the effort of pesantren in shaping the character of discipline of santri that is by applying educative everyday activities and reward and punishment method; (3) rewards given to students in the form of material and non-material. Reward of material is given every semester; and (4) the punishment given has a level of level I, level II, level III and preferential level. Reward and punishment given by boarding school and HISADA as the right hand caretaker.
\end{abstract}

Keywords: discipline character of santri, modern boarding school, reward and punishment.

\begin{abstract}
ABSTRAK
Upaya pendidikan dalam pembentukan karater disiplin salah satunya yaitu dengan menggunakan metode reward dan punishment. Masih jarang lembaga pendidikan yang menggabungkan antara metode reward dan punishment dalam satu wadah. Namun Pondok Pesantren Moderm merupakan lembaga pendidikan islam yang mampu menggabungkan dua metode tersebut dalam satu wadah dan menjadikannya budaya disetiap pondok pesantern modern. seperti yang diterapkan di Pondok Pesantren Modern Daarul Uluum Bantarkemang. Pondok pesantren ini menerapkan metode reward dan punishment dalam mendisiplinkan santri. Tujuan dari penelitian ini adalah memahami reward dan punishment dalam pembentukan karakter disiplin santri. Penelitian ini menggunakan metode kualitatif dengan jenis penelitian etnografi digunakan untuk meneliti nilai budaya yang alamiah. Teknik
\end{abstract}


pengumpulan data dilakukan dengan menggunakan; wawancara, observasi, dan dokumentasi. Analisis data menggunakan; analisis model Spradley, pengumpulan data, reduksi data, display/penyajian data dan verifikasi. Pemeriksaan keabsahan data menggunkanan triangulasi sumber dan menggunakan bahan referensi. Hasil penelitian ini menunjukkan: (1) Pondok Pesantren Modern Daarul Uluum Bantarkemang menggabungkan konsep pembelajaran salafi dan umum, yaitu dengan mempelajari kitab-kitab tradisional dan sekolah madrasah; (2) upaya pesantren dalam membentuk karakter disiplin santri yaitu dengan memerapkan kegiatan sehari-hari yang edukatif dan metode reward dan punishment; (3) reward yang diberikan kepada santri berupa materi dan non materi. Reward berupa materi diberikan setiap satu semester; dan(4) punishment yang diberikan memiliki tingkatan yaitu tigkat I, tingkat II, tingkat III dan tingkat istimewa. Reward dan punishment diberikan oleh pengurus pesantren dan HISADA sebagai tangan kanan pengurus.

Kata kunci: karakter disiplin santri, pondok pesantren modern, reward dan punishment.

Ulfah, R., Fauziah, R. S. P., \& Aliyyah, R. R. (2018). Reward dan Punishment dalam Pembentukan Karakter Disiplin Santri. Tadbir Muwahhid, 2(2), 98-110.

\section{PENDAHULUAN}

Mencetak generasi yang memiliki kepribadian yang tangguh, mandiri, trampil, dan berahlakul karimah adalah tujuan pendidikan karakter. Pendidikan diyakini sebagai salah satu jalan terbaik dalam mewujudkan sumberdaya manusia yang berkualitas, keyakinan tersebut memicu tumbuh kembangnya berbagai model pendidikan yang mengangkat pendidikan kerakter sebagai visi dan misinya.

Pesantren adalah salah satu lembaga pendidikan tertua di Indonesia yang memiliki komotmen yang kuat dalam menerapkan pendidikan karakter . Melihat kepada sejarah pendidikan di tanah air pesantren telah membuktikan eksistensinya dalqam membantu mewujudkan Cita cita Bangsa yang di tuangkan dalam UndangUndang RI yang menyebutkan maksud dan tujuan untuk mewujudkan suasana belajar dan proses pembelajaran agar peserta didik aktif mengembangkan potensi dirinya untuk memiliki kekuatan spiritual, keagamaan, pengendalian diri, kepribadian, kecerdasan, akhlak mulia, serta keterampilan yang diperlukan untuk dirinya, masyarakat, bangsa, dan negara (Undang-Undang RI No 20 Tahun 2003).

Metode pendidikan karakter dalam pendidikan islam dibahas secara sempurna mulai dari keteladanan, perintah, nasihat cerita, ganjaran bahkan metode-metode larangan atau hukuman dan yang lainnya. Reward and punishment adalah salah satu metode dalam pendidikan karakter yang di pesantren yang disebut juga dengan istilah Hadiyah dan hukuman. Konsep hadiah dan hukuman atau reward dan punishment dalam pandangan islam adalah konsep yang sudah jelas tertera secara eksplisit di dalam Alquran dan Hadist .

Dasar agama Islam membolehkan penerapan hukuman dan penghargaan yang dilakukan secara adil dan seimbang. Pesantren sebagai lembaga pendidikan islam tertua memiliki kemapuan dalam menerapkan reward dan punishment namun kadang tidak seimbang seperti lembaga pendidikan lain. hal tersebut dikarenakan hukuman lebih dominan dibanding penghargaan dalam pendidikan kedisiplinan. Walaupun penghargaan diperlukan sebagai motivasi dalam pembelajaran. 
Visi dan kiprah pesantren dalam kerangka pengabdian sosial yang pada mulanya diletakan kepada pembentukan nilai keagamaan, salah satunya dengan menerapkan metode reward dan punishmen. sehingga menumbuhkan karakter kedisiplinan dalam jiwa santri, baik disiplin dalam belajar, disiplin waktu, maupun disiplin peraturan.

Pondok Pesantren modern Daarul Uluum Bantarkemang memiliki visi di dalamnya, yaitu menjadi lembaga pendidikan Islam terpadu yang unggul, sehat, berdisiplin, dan berwawasan global. Untuk mencapai misi pendidikannya, Pondok pesantren Daarul Uluum berkomitmen untuk menerapkan budaya disiplin bagi seluruh santri. Dalam segala bidang di Pondok Pesantren Daarul Uluum ini menerapkan reward dan punishment yang tertulis. Pesantren tidak hanya berfokus pada kemampuan akademik santri, akan tetapi pendidikan harus dipahami sebagai upaya mengiring individu kearah perubahan perilaku ke arah yang lebih baik yaitu dengan adanya peraturan yaitu melalui metode reward dan punishment.

Dafid. L Sills mendefinisikan hadiah yaitu salah satu alat pendidikan yang diberikan pada peserta didik sebagai penghargaan terhadap prestasi atau prilaku baik yang dicapainya (Purwanto, 1985). Sedangkan punishment adalah: 1) suatu penderitaanrasa jera atau rasa tidak senang pada seorang subjek, karena kegagalan dalam menyesuaikan diri terhadap suatu rangkaian perbuatan yang sudah ditentukan terlebih dahulu dalam satu percobaan, 2) Suatu perangsang dengan valensi negative, atau satu perangsang yang mampu menimbulkan kesakitan atau ketidaksenangan, 3) beban yang diberikan dalam periode tertentu atas pelanggaran yang diperbuat oleh seseorang yang sah (Chaplin, 2006).

\section{MATERI DAN METODE}

Penelitian ini menggunakan jenis penelitian kualitatif. Sedangkan pendekatan yang digunakan adalah pendekatan Etnografi. Menurut Sugiyono, jenis penelitian kualitatif adalah cara yang digunakan dalam penelitian suatu objek ilmiah, dimana peneliti semagai instrumen kunci, dan teknik yang digunakan secara triangulasi atau gabungan, serta analisis data bersifat induktif (Sugiyono, 2015).

Sedangkan pendekatan etnografi yaitu suatu studi tentang kebudayaan yang mempelajari kebudayaan lain. Etnografi bermakna membangun suatu pengertian yang sistematik dari suatu kebudayaan manusia dari perspektif orang yang telah mempelajari kebudayaan tersebut (Spradley, 1997).

Sumber data diperoleh dari subyek dalam penelitian yaitu kepala madrasah, ketua asrama putra, ketua asrama putri, HISADA bagian keamanan, HISADA bagian peribadatan dan sntri teladan 2017. Peneliti menggunakan teknik pengumpulan data melalui observasi, wawancara, dan dokumentasi. Selanjutnya untuk menganalisis data yang telah dikumpulkan sejak awal sampai akhir peneliti menggunakan analisis model Miles dan Huberman serta analisis model Spradley. Analisis model Miles dan Huberman meliputi; reduksi data, penyajian data, dan verifikasi kesimpulan (Yusuf, 2016). Sedangkan analisis model Spradley meliputi; analisis domain, analisis taksinomi, analisis komponensial, analisis tema budaya (Spradley, 1997). 


\section{HASIL DAN PEMBAHASAN}

\section{Hasil}

Data atau informasi yang akan di paparkan di bawah ini merupakan hasil temuan penelitian yang didapatkan melalui proses observasi, wawancara dan dokumentasi kepada orang-orang yang ada di Pondok Pesantren Daarul Uluum Bantarkemang yakni kepala madrasah, kepala asrama putri, kepala asrama putra, HISADA bagian keamanan, HISADA bagian peribadatan, dan santri teladan.

\section{Konsep Pesantren di Pondok Pesantren Daarul Uluum Bantarkemang}

Konsep pesantren di Pondok Pesantren Daarul Uluum Bantarkemang mengkombinasikan pembelajaran kitabkitab klasik seperti ta'lim muta'lim, akhlakulil banat dan lain-lain. Mewajibkan para santri mengikuti pembelajaran formal di sekolah dengan mengadakan madrasah jenjang MTs dan MA. Bahasa yang digunakan santri dalam keseharian yaitu menggunakan bahasa Arab dan Inggris.

Dalam buku MAPENPO (masa pengenalan pondok) terdapat penjelasan secara rinci sejarah dan karakteristik pondok Pesantren Daarul Uluum Bantarkemang. Berikut adalah tujuan dan Visi Misi Pondok Pesantren Daarul Uluum Bantarkemang.

\section{Tujuan Pondok Pesantren Daarul Uluum Bantarkemang}

Pondok Pesantren Daarul Uluum Bantarkemang adalah sebuah pondok pesantren modern yang bertanggung jawab untuk menjaga dan memperjuangkan kelangsungan dan kelestarian syari'at islam di tengah masyarakat. Sehingga seluruh santri Pondok pesantren Daarul Uluum berkewajiban untuk menjadikan syari'at
Islam sebagai tuntunan dalam bersikap, bertindak dan berperilaku.

\section{Visi dan Misi Pondok Pesantren Daarul Uluum Bantarkemang}

Pondok Pesantren modern Daarul Uluum Bantarkemang memiliki visi di dalamnya, yaitu menjadi lembaga pendidikan Islam terpadu yang unggul, sehat, berdisiplin, dan berwawasan global. Untuk mencapai misi pendidikannya, Pondok pesantren Daarul Uluum berkomitmen untuk menerapkan budaya disiplin bagi seluruh santri.

\section{Pembentukan Karakter Disiplin Santri}

Menurut informasi yang peneliti dapatkan dari hasil wawancara dengan para pengurus Pondok Pesantren Daarul Uluum Bantarkemang mengenai pembentukan karakter disiplin santri. "Upaya pesantren dalam menumbuhkan karakter disiplin pada diri santri yaitu dengan membiasakan diri melalui kegiatan-kegiatan pesantren. Dengan kegiatan pesantren yang sangat padat santri akan sulit menyianyakan waktunya untuk hal yang tidak penting. Selain itu santri yang tidak mengikuti kegiatan pun akan dihukum sesuai dengan pelangaran yang telah diperbuat".

Kekurangan dari peraturan pesantren yang telah dibuat adalah tidak mencakup seluruh kegiatan santri, karna santri biasanya melanggar tidak terduga sebelumnya. Maka setiap satu semester diadakan evaluasi untuk memperbaharui setiap pelanggaran yang belum tercantum sebelumnya. Evaluasi ini memperbaharui hukuman sesuai dengan situasi dan keadaan santri. Misalnya saja pada zaman sekarang ini sedang viral jual beli online yang dulu belum diketahui oleh masyarakat umum. 
Maka dengan itu hukuman melakukan jual beli online diberlakukan untuk sekarang ini.

Sistem evaluasi yang diterapkan untuk memperbaharui peraturan di lakukan setiap satu semester dan 5 tahun sekali untuk perbaharuan keseluruhan. Hasil revisi atau evaluasi punishment diberikan kepada kepala sekolah dan diketik ulang oleh bidang administrasi.

Hasil revisi akan berbentuk menjadi peraturan dasar pesantren dalam buku MAPENPO 2017 dan paper point punishment. Peraturan dasar ini yang jadi pedoman kedisiplinan untuk semua bidang tidak dalam satu bidang saja namun seluruh bidang yg berkaitan dengan aktifitas pesantren. Adanya pedoman ini adalah salah satu bukti bahwa pendisiplinan karakter santri sangat diutamakan di Pondok Pesantren Daarul Uluum Bantrarkemang.

Hal tersebut sesuai dengan pendapat KM dari hasil Wawancara pada hari Senin tanggal 5 Maret 2018 pukul 8:30 WIB. .....Kekurangan dari peraturan pesantren adalah tidak mencakup seluruh kegiatan santri, karna santri biasanya melanggar tidak terduga sebelumnya seperti pelanggaran jual beli online yang sedang viral sekarang ini.....

Adapun pendapat dari BAA pada hari Kamis tanggal 5 April 2018 pukul 13:00 WIB. .....Evaluasi ini memperbaharui hukuman sesuai dengan situasi dan keadaan santri. Misalnya saja pada zaman sekarang ini sedang viral jual beli online yang dulu belum diketahui oleh masyarakat umum. Maka dengan itu hukuman melakukan jual beli online diberlakukan untuk sekarang ini. Dan Revisi atau evaluasi punishment diberikan kepada kepala sekolah. Diperbaharui setiap satu semester dan 5 tahun sekali untuk perbaharuan keseluruha.....
ST juga berpendapat hal yang sama pada hari Selasa tanggal 10 April 2018 pukul 21:00. ....mudir selalu memberikan tedalan yang baik kepada santri. Beliau mengajarkan bagaimana menjadi santri yang disiplin ilmu, bahasa dan tatakrama. Setiap ba'da Solat Subuh mudir mengajarkan kitab kuning Ta'limuta'lim atau kitab Akhlaqulil Banat. Selain itu beberapa pengurus juga memberikan contoh yang baik walaupun kadang beberapa pengurus HISADA ada yang melanggar peraturan juga....

\section{Reward}

Uluum Bantarkemang dilakukan pada setiap satu semester dan satu tahun sekali. Kyai atau mudir ikut serta dalam kegiatan pemberian reward disetiap akhir tahun ajaran. Setiap bagian diberi tanggung jawabb untuk memberikan reward kepada santri. Proses seleksi pemilihan santri untuk diberikan reward dilakukan oleh HISADA. Setelah HISADA menseleksi lalu ketua bagian pada struktural mengambil alih untuk pemberian reward. Khusus Untuk reward yang berkaitan dengan pengajaran sekolah diseleksi dan diberikan oleh guru atau ustdaz wali kelasnya

Bentuk reward yang diberikan adalah berupa materi dan non materi. Contohnya reward berupa materi yaitu piagam, makanan dan bingkisan berupa alat tulis atau kebutuhan santri lainnya. Untuk reward non materi ini berupa pujian, ucapan motivasi, dan lain sebagainya, hal ini diberikan disetiap hari. Selain itu pengurus juga memberikan reward yang sesuai dengan keinginan santri pada umumnya yaitu mengajak santri jalan-jalan atau makan diluar lingkungan pesantren. Reward ini tentunya hanya diberikan kepada santri teladan dalam bidang asrama.

Hal tersebut sesuai dengan pendapat KM dari hasil Wawancara pada hari Senin 
tanggal 5 Maret 2018 pukul 8:30 WIB. .....Sama seperti punishment, reward pun dilakukan oleh setiap bidang. Reward dilakukan setiap satu semester dan khusus untuk santri teladan dilakukan satu tahun sekali.....

Pernyataan serupa juga disampaikan oleh BAI pada hari Senin tanggal 5 Maret 2018 pukul 10:00 WIB. ....Reward diberikan oleh pengurus HISADA seperti santri teladan dalam bidang ibadah, santri teladan dalam bidang keamanan dan lain sebagainya. Untuk reward yang berkaitan dengan pengajaran sekolah diberikan oleh guru atau ustdaz wali kelasnya. Reward yang diberikan setiap satu semester yang berhubungan dengan nilai. Bentuk rewardnya itu berupa materi dan non materi. Contohnya reward berupa materi adalah piagam, makanan dan bingkisan berupa alat tulis atau kebutuhan santri lainnya. Untuk reward non materi ini berupa pujian, ucapan motivasi, dan lain sebagainya, hal ini diberikan disetiap hari. Selain itu pengurus juga memberikan reward yang sesuai dengan keinginan santri pada umumnya yaitu mengajak santri jalan-jalan atau makan diluar lingkungan pesantren. Reward ini tentunya diberikan kepada santri teladan dalam bidang asrama. Kyai atau mudir ikut serta dalam kegiatan pemberian reward disetiap akhir tahun ajaran....

Adapun pendapat dari BAA pada hari Kamis tanggal 5 April 2018 pukul 13:00 WIB. ....Reward secara materi diberikan setiap setahun sekali. Reward diseleksi oleh masing-masing bagian dan HISADA. Hadiah diberikan oleh bagian asrama dan HISADA sebagai tanggan kanan pengurus. Bentuk riward secara materi yaitu alat-alat yang diperlukan oleh santri seperti alat tulis, jam beker, atau pakaian....

HKA pun berpendapat hal yang sama pada hari selasa tanggal 10 April 2018 pukul 20:30 WIB. .... Reward yang diberikan oleh
HISADA selama satu tahun sekali. Reward diberikan sesuai dengan bidangnya. Yaitu bagian keamanan, bahasa, peribadatan, perpustakaan, dan lain-lain. Bentuk rewardnya berupa materi seperti; alat tulis, pakaian dan vocer belanja di supermarket. Reward dalam bentuk lain yaitu diajak studytour ke pare untuk bagian bahasa. Reward ini khusus untuk santri yang menggunakan bahasa yang telah ditentukan dengan tertib....

\section{Punishment}

Pemberian Punishment dilakukan oleh kepala bagian dan HISADA sebagai tangan kanan pengurus. Khusus untuk Punishment di kelas diberikan oleh guru kelas masingmasing dan staf pengajaran. Bentuk hukumanya yaitu (1) dibotak, dicepak, dipitak; (2) dijemur beserta pamplet yang telah ditentukan sesuai pelanggarannya; (3) putri memakai jilbab warna merah; (4) bersih-bersih lingkungan pesantren; (5) menghafal surat pilihan. Perbedaan punishment santri putra adalah dibotak kepalaya untuk yang keluar pesantren tanpa izin dan hubungan lawan jenis (pacaran).

Hukuman diberikan secara tersusun, tidak langsung diberikan hukuman berat. Punishment di Pondok Pesantren Daarul Uluum Bantarkemang ini ada beberapa tingkatan yang tertulis di peraturan dasar pesantren. Tahapannya adalah pelanggaran tingkat 1, pelanggrana tinggkat 2, pelanggaran tingkat 3 dan pelanggaran istimewa dalam bentuk point. Contoh pelanggaran istimewa adalah tidak melakukan puasa ramadan. Santri yang melakukan pelanggaran berat wajib membuat BAP (Berita Acara Pelanggaran). Adapun pelanggaran yang ringan bisa jadi sedang bahkan berat bila terlalu sering dilakukan, contohnya telat berjamah/masbuk adalah pelanggaran ringan tapi sudah masbuk sebanyak 3 kali 
berturut maka akan berubah menjadi pelanggaran sedang. Contoh lain yaitu tidak mengikuti kegiatan ta'lim pagi adalah pelanggaran sedang namun sudah sering dilanggar maka pelanggarannya berubah menjadi berat. Selain dalam bentuk point, punishment pun ada dalam bentuk kifarat contohnya menghafal satu surat yang dipilih sesuai ketentuan dan sesuai dengan bidang pelanggarannya. Setelah santri dihukum atau diberi kifarat maka point pelanggaran akan otomatis berkurang

Untuk mengetahui santri yang tidak ikut kegiatan atau tidak mematuhi tata tertib adalah dengan mengabsen setiap kegiatan sehingga santri yang tidak hadir tanpa alasan akan dikenakan hukuman. Pada setiap kegiatan pembelajaran baik di kelas maupun peribadatan ada pengawasan rutin sebelum kegiatan dimulai. Bila ada santri yang telat mengikuti kegiatan akan di scots jump atau push up sesuai waktu telatnya. Miasalkan telat lima belas menit berarti 15 scots jump.

Adanya punishment tentu agar ada dampak positif kepada santri. Dampak positif dari pemberian punishment adalah menjadikan rabu-rambu waspada kepada santri yang lain agar tidak melakukan pelanggaran, sehingga para santri dapat mengikuti peraturan yang ada. Adapun dampak negatif dari pemberian pinishment yaitu santri yang dihukum merasa sudah tercoreng nama baiknya sehingga dia melakukan pelanggaran yang sama pun tidak ia takuti. Dengan adanya punishment santri bisa dikit demisedikit mematuhi peraturan yang ada. Karena pada dasarnya kebiasaan baik diawali dengan dibiasakan lalu biasa melakukan setelah itu terbiasa melakukan.

Hal serupa disampaikan oleh BAI pada hari Senin tanggal 5 Maret 2018 pukul 10:00 WIB. ...hukuman diberikan berupa nilai point dan kifarat. Jika santri melakukan kifarat secara otomatis point akan berkurang. Tujuan diberikan hukuman yaitu untuk mendisiplinkan santri...

Adapun pendapat dari BAA pada hari Kamis tanggal 5 April 2018 pukul 13:00 WIB. ....HISADA bagian keamanan sebagai tangan kanan para ustadz yang mengurus reward dan punishment dalam lingkup asrama. Untuk punishmen di kelas punishment dikelola oleh bagian pengajaran. Perbedaan punishment santri putra adalah dibotak kepalaya untuk yang keluar pesantren tanpa izin dan hubungan lawan jenis. Jenis punisment lain seperti hafalan, diberikan tugas membangunkan santri lain untuk ta'lim subuh dengan jangka waktu tertentu....

HPI pun berpendapat hal yang sama pada hari selasa tanggal 10 April 2018 pukul 20:30 WIB. ....pemberian hukuman adalah cara yang paling berpengaruh dalam kedisiplinan santri, sebab santri menjadi merasa tidak nyaman ketika diberi hukuman walaupun beberapa santri ada yang sulit untuk dikendalikan dengan hukuman....

\section{Pembahasan}

\section{Konsep Pesantren}

Pondok pesantren Daarul Uluum Bantarkemang termasuk kedalam jenis Pesantren modern. Hal ini dikarenakan pembelajarannya yang mengkombinasikan pendidikan salafi dan mengadopsi pendidikan umum dengan kurikulum nasional dan kurikulum lokal seperti penanaman bahasa arab dan lain-lain. Tujuan dari pembelajaran pesantren modern ini adalah supaya santri mampu hidup dalam situasi sosial apapun.

Pernyataan di atas sesuai dengan teori konsep pesantren modern yaitu (Efrizal, 2012): "Modern Islamic boarding schools 
interpreted as educational institutions, where the students usually stay in the lodge (dormitory) with Islamic teaching materials of classical books and general books of scientific knowledge, aiming to master the science of the Islamic religion in detail and along with general sciences such as mastery of foreign language and apply it as well as guidance in daily lives by emphasizing the importance of morality in social life" yang artinya Pesantren Modern diartikan sebagai lembaga pendidikan, di mana para siswa biasanya tinggal di pondok (asrama) dengan bahan pengajaran Islam, buku klasik dan buku umum pengetahuan ilmiah, bertujuan untuk menguasai ilmu agama Islam secara rinci dan bersama dengan ilmu-ilmu umum seperti penguasaan bahasa asing dan menerapkannya serta bimbingan dalam kehidupan sehari-hari dengan menekankan pentingnya moralitas dalam kehidupan sosial.

\section{Pembentukan Karakter Disiplin Santri}

Karakter disiplin santri merupakan hal mendasar dalam penetapan peraturan yang ada di Pondok Pesantren Daarul Uluum Bantarkemang. Upaya yang dilakukan dalam pembentukan karakter disiplin yaitu dengan membuat program kegiatan yang mendidik dan berkarakter. Sehingga santri akan terbiasa dan terlatih dalam dirinya untuk melakukan kegiatan positif baik di dalam pesantren maupun di luar pesantren. Pembentukan karakter disiplin dan kemandirian santri yang dilakukan melalui aturan yang dibuat oleh stakeholders pondok pesantren modern Daarul Uluum Bantarkemang juga sesuai dengan konsep yang diterapkan oleh pondok pesantren Darussyifa Al-fitroh Yaspida Sukabumi (Aliyyah \& Rahmah, 2017). Hal tersebut juga sesuai dengan pendapat (Efrizal, 2012):
"Basically, discipline is a basic requirement for the development of children's behavior because this period is very effective to create the moral behavior. Discipline is needed to help the child's personal and social adjustment. Through discipline, children can learn to behave through manner approved by the social environment" yang artinya pada dasarnya, disiplin merupakan persyaratan dasar untuk perkembangan perilaku anak-anak karena periode ini sangat efektif untuk menciptakan perilaku moral. Disiplin diperlukan untuk membantu penyesuaian pribadi dan sosial anak. Melalui disiplin, anak-anak dapat belajar untuk berperilaku melalui cara yang disetujui oleh lingkungan sosial.

Selain dengan pembuatan program kegiatan santri yang edukatif, menjalin komunikasi dan hubungan baik dengan orang tua merupakan hal penting. Pada awal pendaftaran santri baru, orangtua wali santri wajib melakukan ijab kabul penyerahan pendidikan anaknya kepada pihak pesantren dan melakukan perjanjian tertulis. Saat santri berada di pesantren, kedua pihak yaitu pengurus pesantren dan orangtua saling berkomunikasi agar orangtua tau kondisi anaknya seperti apa dan mempermudah penyelesaian masalah jika anaknya melanggar peraturan pesantren. Ketika masa liburan pihak pesantren menyerahkan tanggung jawab santri kepada orangtuanya namun hubungan baik dengan pesantren masih tetap terjalin. Komunikasi dan hubungan baik dengan orangtua merupakan hal terpenting dalam pembentukan kedisiplinan santri.

Hal tersebut serupa dengan yang dikemukakan Vladimir (Efrizal, 2012): "parents and teachers have significant roles in instilling the discipline towards children 
because parents and teachers are the closest children neighborhoods. The disciplinary rules that were implemented must form a new agreement between house and school" yang artinya orang tua dan guru memiliki peran penting dalam menanamkan disiplin terhadap anak-anak karena orang tua dan guru adalah lingkungan anak-anak terdekat. Aturan pendisiplinan yang diterapkan harus membentuk perjanjian baru antara rumah dan sekolah.

Peraturan di Daarul Uluum Bantarkemang tidak sertamerta dibuat begitu saja, namun peraturan dibuat tersusun dan sesuai dengan situasi yang ada. Agar peraturan konsisten dan terorganisir maka sertiap satu tahun sekali dilakukan evaluasi untuk memperbaharui peraturan dan direvisi setiap lima tahun sekali. Hasil revisi akan dikelola oleh kepala madrasah dan bidang administrasi agar peraturan yang diperbaharui masuk kedalam buku pedoman pesantren.

Hal tersebut serupa dengan yang dikemukakan oleh (Rahayuningsih \& Sholikhan, 2016): "the rule that was already implemented should be consistent and wellorganized in order to become a clear guidelines for children to behave" yang artinya aturan yang sudah dilaksanakan harus konsisten dan terorganisasi dengan baik agar menjadi pedoman yang jelas bagi anak-anak untuk berperilaku.

\section{Reward}

Reward di Daarul Uluum Bantarkemang dilakukan untuk mendidik santri terpacu kearah yang lebih baik lagi. Dengan memahami perasaan tiap individu santri dan memacu santri lain agar melakukan halhal positif. Melakukan pendekatan sehingga santri tidak merasa iri hari kepada santri yang mendaptkan reward dan Melakukan analisis dari catatan-catan pelanggran santri. Maka pengurus harus memilih santri mana yang berhak mendapatkan reward baik di asrama maupun dalam pembelajaran.

Reward yang dilakukan di Pondok Pesantren Daarul Uluum sesuai dengan teori prinsip pemberian reward yang dikemukanan oleh Tom sebagai berikut (Kelishadroky, Sahmsi, Bagheri, Shahmirzayi, \& Mansorihasanabadi, 2016): "Principle One: Choosing the right reinforcing agents Different agents have different results for various individuals. Even the same agent yields differing results on the same person under various conditions. This should be carefully considered in any situation and with any individual" yang artinya prinsip satu: Memilih agen penguat yang tepat. Agen yang berbeda memiliki hasil yang berbeda untuk berbagai individu. Bahkan agen yang sama menghasilkan hasil yang berbeda pada orang yang sama dalam berbagai kondisi. Ini harus dipertimbangkan dengan saksama dalam situasi apa pun dan dengan individu mana pun.

Pemberian reward diberikan dan ditetapkan setiap satu semester tepatnya setiap pergantian semester dan kenaikan kelas. Momen pemberian reward ini sangat cocok dikarenakan setiap pergantian semester merupakan pembagian rapot hasil belajar, dan setiap kenaikan kelas merupakan waktu untuk libur panjang santri di akhir pembelajaran baik pembelajran pesantren maupun sekolah.

Hal tersebut juga sesuai dengan prinsip pemberian reward yang kedua, yaitu: "Principle Two: Reward immediately after the behavior to have the best result The biggest mistake any parent can make is to delay the reward for an appropriate behavior. A reward will be most effective if it immediately follows the behavior so that 
the desirable behavior is validated" yang artinya Prinsip Dua: Hadiahi segera setelah perilaku untuk mendapatkan hasil terbaik Kesalahan terbesar yang dapat dilakukan orangtua adalah menunda hadiah untuk perilaku yang sesuai. Hadiah akan sangat efektif jika segera mengikuti perilaku sehingga perilaku yang diinginkan divalidasi.

Bentuk dari reward yang diberikan pun sesuai dengan kebutuhan santri, segingga santri merasa kebutuhannya tercukupi dan semakin bersemangat untuk melakukan kegiatan di pesantren. Bentuk yang diberikan misalnya alat tulis, peratalan solat, pakaian muslim dan lain sebagainya.

Hal tersebut juga sesuai dengan prinsip pemberian reward yang ketiga, yaitu: "Principle five: Reward must make the child a better person and guide that person toward goals. It must also lead to increased effort and overall create a better human being. The toys given to a child must enable him/her to think and become actively involved in innovation. For instance, instead of a winding car, the child should be able to play with building blocks" yang artinya hadiah harus membuat anak menjadi orang yang lebih baik dan membimbing orang itu menuju tujuan. Itu juga harus mengarah pada peningkatan upaya dan secara keseluruhan menciptakan manusia yang lebih baik. Mainan yang diberikan kepada seorang anak harus memungkinkan dia berpikir dan menjadi aktif terlibat dalam inovasi. Misalnya, daripada mobil yang berliku, anak harus bisa bermain dengan balok bangunan.

\section{Punishment}

Hukuman atau punishment di Daarul Uluum tertulis dalam pedoman pesantren. Adapun empat tingkat pelanggran yang tertera dalam pedoman pesantren yaitu tingkat I (sederhana), tingkat II (sedang), tingkat III (tinggi) dan tingkat istimewa. Setiap tingkatan jenis hukumannya berbedabeda disesuaikan dengan pelanggaran yang dilakukan.

Pemberian punishment di Daarul Uluum sudah memenuhi syarat yang dikemukanan oleh Milton (Kelishadroky, Sahmsi, Bagheri, Shahmirzayi, \& Mansorihasanabadi, 2016), sebagai berikut.

"1) Punishment must be appropriate to the fault and immediately follow it so that the student understands his fault" yang artinya hukuman harus sesuai dengan kesalahan dan segera mengikutinya sehingga siswa memahami kesalahannya.

Hukuman diberlakukan apabila cara lain tidak efektif diberikan kepada santri. Upaya sebelum diberi hukuman yaitu dengan memberikan nasihat terutama kepada santri yang melakukan pelanggaran berat dan istimewa.

Pernyataan tersebut sesuai dengan syarat yang kedua yaitu:

"2) Before punishment, the reason for the undesirable behavior should be identified and appropriate guidance must be given. If all else fails, punishment must be resorted to as a last measure" yang artinya sebelum hukuman, alasan untuk perilaku yang tidak diinginkan harus diidentifikasi dan bimbingan yang tepat harus diberikan. Jika semuanya gagal, hukuman harus digunakan sebagai langkah terakhir"

Peraturan yang ditetapkan di pesantren disetujui dan dilakukan oleh tiap bidang didalam struktur organisasi pesantren. Dalam evaluasi peraturan pesantren setiap bidang memastikan hukuman yang berlaku harus sesuai dengan keadaan santri baik keadaan fisik maupun mental satri. Misalnya saja hukuman bagi santri putra yang berpacaran yaitu dibotak agar santri merasa 
enggan untuk bertemu dengan lawan jenisnya lagi.

Hal diatas selaras dengan syarat pemberian punishment yang ke tiga dan kesempat, yaitu:

"3) The teacher must make certain that the effect and result of the punishment must justify its application: 4) The teacher must be permitted by the parts to punish the student" yang artinya guru harus memastikan bahwa efek dan hasil dari hukuman harus membenarkan penerapannya: 4) Guru harus diizinkan oleh bagian-bagian untuk menghukum siswa.

Untuk menetapkan santri yang diberihukuman, pengurus oesantren berkoordinasi dengan pengurus HISADA agar tidak salah dalam menetapkan. Setiap kegiatan santri diawasi oleh pengurus HISADA berbidangnya. Sehingga yang tahu persis seperti apa pelaksanaan dan keadaan kegiatan dipesantren adalah HISADA. Selain itu HISADA pun membuat catatan santri yang melanggar peraturan yang ada.

Senada dengan pendapat tom dalam syarat pemeberian punishment yang kelima dan ke enam, yaitu:

"5) The negative reinforcement agent must be identified carefully; 6) Prior to punishment, necessary information regarding possible interventions must be gathered" yang artinya agen penguat negatif harus diidentifikasi dengan hati-hati; 6) Sebelum hukuman, informasi yang diperlukan mengenai kemungkinan intervensi harus dikumpulkan.

\section{KESIMPULAN DAN IMPLIKASI}

\section{Kesimpulan}

Penelitian yang telah dilakukan di Pondok Pesantren Modern Daarul Uluum
Bantarkemang maka disimpulkan sebagai berikut.

1. Konsep pesantren di Pondok Pesantren modern Daarul Uluum Bantarkemang

Konsep pesantren di Pondok pesantren Daarul Uluum Bantarkemang mengkombinasikan antara pendidikan pesantren salafi dan pendidikan umum. Mempelajari kitab kuning Ta'limu ta'lim dan kitab Akhlakulil banat. Mewajibkan para santri mengikuti pembelajaran formal di sekolah dengan mengadakan madrasah jenjang MTs dan MA. Bahasa yang digunakan dalam kehidupan sehari-hari yaitu menggunakan bahasa Arab dan Inggris. Pondok pesantren Daarul Uluum Bantarkemang termasuk kedalam jenis Pesantren modern. Hal ini dikarenakan pembelajarannya yang mengkombinasikan pendidikan salafi dan mengadopsi pendidikan umum dengan kurikulum nasional dan kurikulum lokal seperti penanaman bahasa arab dan lain-lain.

2. Pembentukan karakter disiplin santri di Pondok Pesantren modern Daarul Uluum Bantarkemang

Metode yang digunakan dalam pembentukan karakter disiplin santri yaitu dengan membuat program kegiatan yang mendidik dan berkarakter. Kegiatan dari awal santri mendaftar masuk ke pesantren sudah diberikan kegiatan pendisiplinan yaitu dengan ijab kabul dengan orangtua wali santri. Kegiatan pendisiplinan seharihari santri mengunakan metode reward dan punishment. Selain reward dan punishment terdapat kegitan lain seperti pengajian kitab kuning mengenai adabadab seorang santri.

3. Reward di Pondok Pesantren modern Daarul Uluum Bantarkemang 
Reward di Pondok Pesantren Daarul Uluum Bantarkemang dilakukan pada setiap satu semester dan satu tahun sekali. Setiap bagian diberi tanggung jawabb untuk memberikan reward kepada santri. Proses seleksi pemilihan santri untuk diberikan reward dilakukan oleh HISADA. Setelah HISADA menseleksi lalu ketua bagian pada struktural mengambil alih untuk pemberian reward. Bentuk reward yang diberikan adalah berupa materi dan non materi. Contohnya reward berupa materi yaitu piagam, makanan dan bingkisan berupa alat tulis atau kebutuhan santri lainnya. Untuk reward non materi ini berupa pujian, ucapan motivasi, dan lain sebagainya, hal ini diberikan disetiap hari. Selain itu pengurus juga memberikan reward yang sesuai dengan keinginan santri pada umumnya yaitu mengajak santri jalanjalan atau makan diluar lingkungan pesantren. Reward ini tentunya hanya diberikan kepada santri teladan dalam bidang asrama.

4. Punishment di Pondok Pesantren modern Daarul Uluum Bantarkemang

Punishment di Pondok Pesantren Daarul Uluum Bantarkemang ini ada beberapa tingkatan yang tertulis di peraturan dasar pesantren. Tahapannya adalah pelanggaran tingkat 1 , pelanggrana tinggkat 2 , pelanggaran tingkat 3 dan pelanggaran istimewa dalam bentuk poin. Bentuk hukumanya yaitu (1) dibotak, dicepak, dipitak; (2) dijemur beserta pamplet yang telah ditentukan sesuai pelanggarannya; (3) putri memakai jilbab warna merah; (4) bersih-bersih lingkungan pesantren; (5) menghafal surat pilihan. Perbedaan punishment santri putra adalah dibotak kepalaya untuk yang keluar pesantren tanpa izin dan hubungan lawan jenis (pacaran).

\section{Implikasi}

Penelitian ini hanya mencakup penerapan reward dan punishment dalam pemebentukan karakter santri, sehingga penelitian masih banyak informasi lain yang harus digali baik dari administrasinya maupun implementasi lainya. Namun penelitian ini diharapkan dapat menjadi sumber referensi untuk penelitian yang relevan bagi penelitian lain.

Selain itu wujud adanya penelitian ini memberikan masukan terhadap lembaga pendidikan lain dan memberikan pengalaman berharga bagi peneliti. Maka sangat diharapkan pula lembaga pendidikan lain dapat memiliki metode reward dan punishment yang baik dalam pembentukan karakter disiplin peserta didiknya. Sehingga memberikan nilai lebih untuk lembaga tersebut sekaligus memiliki kualisan pendidikan yang sesuai dengan harapan masyarakat.

\section{DAFTAR PUSTAKA}

Aliyyah, R. R., \& Rahmah, S. (2017). Pendidikan Kemandirian Berbasis Kewirausahaan. Tadbir Muwahhid, 1(2), 142-152.

Chaplin, J. P. (2006). Kamus Lengkap Psikologi. Jakarta: Raja Grafindo Persada. Efrizal, D. (2012). Improving Student's Speaking Through Communicative languange Teaching Method at Mts Jaalhaq, Sentot Ali Basa Islamic Boarding School of Bengkulu, Indoneis. Internasional Journal of Humanities and Scocial Science, 2(20), 127-134.

Kelishadroky, A. F., Sahmsi, A., Bagheri, M., Shahmirzayi, B., \& Mansorihasanabadi, M. (2016). The Role of Reward and 
Punishment in Learning. Internasional Journal of advanced Biotechnology and Research, 780-788.

Purwanto, M. N. (1985). Ilmu Pendidikan, Teoritis dan Praktis. Bandung: Remadja Karya.

Rahayuningsih, S., \& Sholikhan. (2016). Disciplinary Character Educatin at Early Age. Journal of Reserach \& Method in Education (IOSR-JRME), 6(5), 122-135.
Spradley, J. P. (1997). Metode Etnografi. Yogya: Tiara Wacana Yogya.

Sugiyono. (2015). Metode Penelitian Kuantitatif, Kualitatif dan R7D. Bandung: Alfabeta.

Yusuf, A. M. (2016). Metode Penelitian Kualitatif, Kuantitatif dan Penelitian Gabungan. Jakarta: Prenada Media. 